\title{
KLF5 regulates infection- and inflammation-induced pro-labour mediators in human myometrium
}

\author{
Martha Lappas ${ }^{1,2}$ \\ ${ }^{1}$ Mercy Perinatal Research Centre, Mercy Hospital for Women, Heidelberg, Victoria, Australia and ${ }^{2}$ Obstetrics, \\ Nutrition and Endocrinology Group, Department of Obstetrics and Gynaecology, Mercy Hospital for Women, \\ University of Melbourne, Level 4, 163 Studley Road, Heidelberg, Victoria 3084, Australia
}

Correspondence should be addressed to M Lappas; Email: mlappas@unimelb.edu.au

\begin{abstract}
The transcription factor Kruppel-like factor 5 (KLF5) has been shown to associate with nuclear factor kappa B (NFKB) to regulate genes involved in inflammation. However, there are no studies on the expression and regulation of KLF5 in the processes of human labour and delivery. Thus, the aims of this study were to determine the effect of i) human labour on KLF5 expression in both foetal membranes and myometrium; ii) the pro-inflammatory cytokine interleukin 1 beta (IL1 $\beta)$, bacterial product flagellin and the viral dsRNA analogue poly(I:C) on KLF5 expression and iii) KLF5 knockdown by siRNA in human myometrial primary cells on pro-inflammatory and pro-labour mediators. In foetal membranes, there was no effect of term or preterm labour on KLF5 expression. In myometrium, the term labour was associated with an increase in nuclear KLF5 protein expression. Moreover, KLF5 expression was also increased in myometrial cells treated with IL1 $\beta$, flagellin or poly(IC), likely factors contributing to preterm birth. KLF5 silencing in myometrial cells significantly decreased IL1 $\beta$-induced cytokine expression (IL6 and IL8 mRNA expression and release), COX2 mRNA expression, and subsequent release of prostaglandins $\mathrm{PGE}_{2}$ and $\mathrm{PGF}_{2 \alpha}$. KLF5 silencing also significantly reduced flagellin- and poly(l:C)-induced IL6 and IL8 mRNA expression. Lastly, IL1 $\beta$-, flagellin- and poly(I:C)-stimulated NFKB transcriptional activity was significantly suppressed in KLF5-knockout myometrial cells. In conclusion, this study describes novel data in which KLF5 is increased in labouring myometrium, and KLF5 silencing decreased inflammation- and infection-induced pro-labour mediators.

Reproduction (2015) 149 413-424
\end{abstract}

\section{Introduction}

Kruppel-like factor (KLF) transcription factors are involved in the development of various human diseases, such as obesity, cardiovascular disease, cancer and inflammatory conditions (Turner \& Crossley 1999, Dang et al. 2000, Black et al. 2001, Kaczynski et al. 2003, McConnell \& Yang 2010). In humans, the KLF family consists of $\sim 20$ members which are structurally characterised by three tandem zinc-finger domains at the C-terminus. KLF5, also named BTEB2 (Sogawa et al. 1993), is ubiquitously expressed (Sogawa et al. 1993, Shi et al. 1999) and is primarily expressed in the nucleus (Shi et al. 1999). KLF5 is a transcription factor and thought to be active only in the nucleus where it binds directly to a specific recognition motif in the promoters of target genes. KLF5 has been demonstrated to regulate many genes involved in cell cycle regulation, apoptosis, migration, differentiation and inflammation (Ghaleb et al. 2005, Chanchevalap et al. 2006, Kumekawa et al. 2008, Shinoda et al. 2008, Wan et al. 2008). The KLF5 protein has been shown to associate with numerous transcription factors, including nuclear factor kappa B (NFאB), to regulate gene transcription (Sur et al. 2002, Aizawa et al. 2004).

There is limited data on the role of KLF5 in the regulation of inflammation; however, the available evidence suggests that KLF5 exerts pro-inflammatory actions. In vitro, knockdown of KLF5 by siRNA inhibits tumor necrosis factor alpha (TNF $\alpha$ )-induced expression of the chemokine MCP1 (Kumekawa et al. 2008) and lipopolysaccharide (LPS)-induced NFKB expression and its downstream target genes, including $T N F \alpha$ and interleukin 6 (IL6) (Chanchevalap et al. 2006, Chen et al. 2014). In vivo, KLF5 initiates the accumulation of M1 macrophages and regulates the inflammation of tubulointerstitium in the unilateral ureteral obstruction (UUO) mouse (Fujiu et al. 2011), and the overexpression of KLF5 in distal tubule cells is associated with increased production of pro-inflammatory cytokines in kidney tissues of young rats fed with melamine and cyanuric acid (Huang et al. 2013).

Human labour is associated with inflammation. During labour there is increased expression of proinflammatory mediators. These include pro-inflammatory cytokines, such as IL $1 \beta, I L 6$ and IL8 in the cervix, 
myometrium, foetal membranes and placenta (Denison et al. 1998, Young et al. 2002, Osman et al. 2003); prostaglandins $\mathrm{PGE}_{2}$ and $\mathrm{PGF}_{2 \alpha}$ in the foetal membranes and myometrium (Olson 2003); and matrix metalloproteinase 9 (MMP9) in the placenta and foetal membranes (Xu et al. 2002). Regulation of these mediators facilitates tissue remodelling of the cervix, myometrial contractions and rupture of membranes, leading to successful delivery at term. It is untimely activation of these processes that can lead to spontaneous preterm birth (Goldenberg et al. 2008). In gestational tissues, expression of cytokines and prostaglandins is regulated by the transcription factor NFkB (Belt et al. 1999, Lappas et al. 2002). The activation of $\mathrm{NF \kappa B}$ is tightly controlled, with both intracellular and extracellular feedback control; inflammatory stimuli such as cytokines and bacterial products (e.g. LPS) activate NFKB, which enhances cytokine production that further amplifies the original inflammatory signal (Hayden \& Ghosh 2004). It is in fully understanding the mechanisms that drive human labour that we can begin to develop therapeutics for the prevention or management of preterm labour.

KLF5 is expressed in human placenta (Bai et al. 2012), and in the mouse uterus where it plays an essential role in implantation (Sun et al. 2012). However, there are no studies on KLF5 in foetal membranes and myometrium and its role in the regulation of inflammation. In nongestational tissues, KLF5 is induced by a number of inflammatory stimuli (Bafford et al. 2006, Kumekawa et al. 2008, Noto et al. 2013, Chen et al. 2014) where it exerts pro-inflammatory actions (Chanchevalap et al. 2006, Kumekawa et al. 2008, Chen et al. 2014). Thus, the hypothesis to be tested is that KLF5 is increased in foetal membranes and myometrium with human labour, and inhibition of KLF5 is associated with decreased expression of pro-inflammatory and pro-labour mediators. The aims of this study were to determine the effect of i) human term and preterm spontaneous labour on KLF5 expression in human foetal membranes and myometrium and ii) KLF5 siRNA knockdown on pro-inflammatory and pro-labour mediators in primary cells isolated from human myometrium.

\section{Materials and methods}

\section{Tissue collection}

The Research Ethics Committee of Mercy Hospital for Women approved this study. Written, informed consent was obtained from all participating women. All tissues were obtained from women who delivered healthy, singleton infants. All tissues were processed within $15 \mathrm{~min}$ of delivery. Women with any underlying medical conditions such as diabetes, asthma, polycystic ovarian syndrome, preeclampsia and macrovascular complications were excluded. Women with multiple pregnancies, obese women and foetuses with chromosomal abnormalities were also excluded.
For expression studies by western blotting, foetal membranes were obtained from women at i) term no labour undergoing elective Caesarean section (indications for Caesarean section were breech presentation and/or previous Caesarean section; $n=6$ patients; mean gestational age $38.8 \pm 0.3$ weeks) and ii) term after spontaneous labour, spontaneous membrane rupture and normal vaginal delivery $(n=6$ patients; mean gestational age $38.7 \pm 0.4$ weeks). Foetal membranes from the non-labouring group were obtained from the supracervical site (SCS). Identification of the SCS was performed as previously detailed (Lappas et al. 2011). Briefly, Bonneys blue dye was introduced through the cervix before Caesarean section. Upon delivery of the placenta, a blue mark was obvious on the chorion-facing membrane where the dye had been applied. In the after-labour group, foetal membranes from the site of membrane rupture (SOR) as previously described (Lappas et al. 2011). Amnion and underlying choriodecidua were collected from along the line of foetal membrane rupture. There was no difference in maternal age and $\mathrm{BMI}$, parity or gestational age of the patients recruited. In the term after-labour group, none of the patients received any medications to augment or induce labour, and the average length of labour was $6 \mathrm{~h} 40 \min \pm 1 \mathrm{~h}$ $40 \mathrm{~min}$. Tissue samples were snap frozen in liquid nitrogen and immediately stored at $-80^{\circ} \mathrm{C}$ for western blotting analysis as detailed below. Full thickness extra-placental membranes (obtained $\sim 2 \mathrm{~cm}$ from the peri-placental edge) were also collected, fixed and paraffin embedded for immunohistochemical analysis.

Foetal membranes were also obtained from women at preterm (without histological chorioamnionitis) from two groups: i) no labour undergoing Caesarean section $(n=6$ patients; mean gestational age $32.8 \pm 0.7$ weeks) and ii) after spontaneous labour and normal vaginal delivery $(n=6$ patients; mean gestational age $32.5 \pm 0.8$ weeks). All placentas collected from the two preterm groups were swabbed for microbiological culture investigations and histopathological examination. Histologic chorioamnionitis was diagnosed based on the presence of inflammatory cells in the chorionic plate and/or chorioamniotic membranes. Indications for preterm delivery (in the absence of labour) were placenta praevia, placental abruption or antepartum haemorrhage. For these studies, foetal membranes from both the non-labouring and after-labour preterm groups were obtained $2 \mathrm{~cm}$ from the peri-placental edge. The tissue samples were snap frozen in liquid nitrogen and immediately stored at $-80{ }^{\circ} \mathrm{C}$ for western blotting analysis as detailed below.

Myometrium was obtained from consenting women at the time of term Caesarean section ( $\geq 37$ weeks gestation). Myometrial biopsies were collected from two groups of women: i) pregnant women undergoing elective Caesarean section in the absence of labour ( $n=6$ patients; mean gestational age $39.4 \pm 0.3$ weeks) and ii) pregnant women who were delivered during active labour; labour was defined as the presence of regular uterine contractions (every 3-4 min) resulting in cervical effacement and dilation $(n=6$ patients; mean gestational age $39.8 \pm 0.2$ weeks). Women were excluded from the study if they had a multiple pregnancy, evidence of active infection. A myometrial biopsy was obtained from the upper margin of the lower uterine segment 
incision during the Caesarean section. There was no difference in maternal age and BMI, parity or gestational age of the patients recruited. In the term laboring group, none of the patients received any medications to augment or induce labour, and the average length of labour was $10 \mathrm{~h} \pm 6 \mathrm{~h}$ $40 \mathrm{~min}$. Tissue samples were fixed and paraffin embedded for immunohistochemical analysis, or snap frozen in liquid nitrogen and immediately stored at $-80{ }^{\circ} \mathrm{C}$ for western blotting analysis as detailed below.

\section{Gene silencing of KLF5 with siRNA}

Primary myometrial cells were used to investigate the effect of KLF5 siRNA knockdown on pro-labour mediators. Myometrium was obtained from women who delivered healthy, singleton infants at term (37-41 weeks gestation) undergoing elective Caesarean section in the absence of labour. The cells were isolated and cultured as previously described (Lim et al. 2013a). Briefly, myometrium was minced and digested for $1 \mathrm{~h}$ in DMEM/nutrient mixture F-12 Ham (DMEM/F-12) with 3 mg/ $\mathrm{ml}$ type 1 collagenase (Worthington Biochemical, Freehold, $\mathrm{NJ}$, USA) and $80 \mu \mathrm{g} / \mathrm{ml}$ DNase 1 (Roche Diagnostics) at $37^{\circ} \mathrm{C}$. The cells were centrifuged at $400 \mathrm{~g}$ for $10 \mathrm{~min}$ and grown in DMEM/F-12 enriched with 10\% heat-inactivated FCS (containing $100 \mathrm{U} / \mathrm{ml}$ penicillin $\mathrm{G}$ and $100 \mathrm{mg} / \mathrm{ml}$ streptomycin). Myometrial cells from passages 1 to 4 were used. The cells at $\sim 50 \%$ confluence were transfected using Lipofectamine 3000 reagent according to the manufacturer's guidelines (Life Technologies). KLF5 siRNA (HSC.RNAI.N001730.12.1) was obtained from Integrated DNA Technologies (Coralville, IA, USA) and the negative control (NC) siRNA was obtained from Sigma. The cells were transfected with $200 \mathrm{nM} \mathrm{KLF5}$ or $200 \mathrm{nM}$ NC siRNA in DMEM/F-12 for $48 \mathrm{~h}$. The medium was then replaced with DMEM/F-12 (containing 0.5\% BSA) with or without $1 \mathrm{ng} / \mathrm{ml} \mathrm{IL} 1 \beta, 5 \mu \mathrm{g} / \mathrm{ml}$ poly(I:C) or $1 \mu \mathrm{g} / \mathrm{ml}$ flagellin, and the cells were incubated at $37^{\circ} \mathrm{C}$ for an additional $24 \mathrm{~h}$. The cells were collected and stored at $-80^{\circ} \mathrm{C}$ until assayed for mRNA expression by quantitative RT-PCR (qRT-PCR) and protein expression by western blotting as detailed below. Media was collected and stored at $-80{ }^{\circ} \mathrm{C}$ until assayed for cytokine and prostaglandin release as detailed below. The response to IL1 $\beta$, poly $(\mathrm{I}: \mathrm{C})$ or flagellin between patients varied greatly, as previously reported (Lim et al. 2013a). Thus, data are presented as fold change relative to IL1 $\beta-$, poly(I:C)- or flagellin-stimulated NC siRNA-transfected cells, which was set at 1. Experiments were performed from myometrium obtained from five individual patients.

\section{$N F_{K} B$ luciferase assay}

A luciferase assay was used to determine possible interactions between KLF5 and NFKB, as previously described (Lim et al. 2013a). Primary myometrial cells, prepared as described previously, at $\sim 70 \%$ confluence, were transfected with $0.75 \mathrm{ng} N \mathrm{~N}_{\kappa} \mathrm{B}$ reporter construct (Qiagen) using FuGENE HD Transfection Reagent (Promega). After $6 \mathrm{~h}$, cells were transfected with $200 \mathrm{nM}$ KLF5 or NC siRNA (as detailed above) for $48 \mathrm{~h}$. The medium was then replaced with DMEM/F-12 (containing $0.5 \%$ BSA), with or without $1 \mathrm{ng} / \mathrm{ml} \mathrm{IL1} \beta, 5 \mu \mathrm{g} / \mathrm{ml}$
poly(l:C) or $1 \mu \mathrm{g} / \mathrm{ml}$ flagellin, and the cells were incubated at $37^{\circ} \mathrm{C}$ for an additional $24 \mathrm{~h}$. The cells were harvested in lysis buffer, and luminescence activity was measured using the Luciferase Reporter Assay Kit (Life Research, Scoresby, VIC, Australia) and Renilla Luciferase Flash Assay Kit (Thermo Fisher Scientific, Scoresby, VIC, Australia) as instructed. The ratio of the firefly luciferase level to the Renilla luciferase level was determined and the results are expressed as a ratio of normalised luciferase activity of IL1 $\beta-$, poly(I:C)- or flagellin-

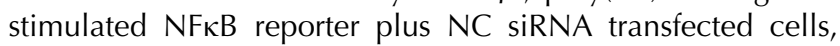
which was set as 1 . The experiments were performed from myometrium obtained from five patients.

\section{Immunohistochemistry}

To determine the localisation of KLF5 in foetal membranes and myometrium, immunohistochemistry was performed on paraffin sections as described previously (Lim et al. 2013a) using the IHC Select HRP Detection Set (Merck Millipore, Billerica, MA, USA). Briefly, sections were deparaffinised followed by an antigen retrieval step (boiled in $10 \mathrm{mM}$ Tris, $1 \mathrm{mM}$ EDTA, $\mathrm{pH} 9.0$ for $10 \mathrm{~min}$ followed by $20 \mathrm{~min}$ incubation) and then endogenous peroxidases were inactivated by adding $3 \%$ hydrogen peroxide for $10 \mathrm{~min}$. After blocking (Blocking Reagent: normal goat serum in PBS) for $5 \mathrm{~min}$, sections were incubated with $2 \mu \mathrm{g} / \mathrm{ml}$ rabbit polyclonal anti-KLF5, \#GTX103289 (GeneTex, Inc., Irvine, CA, USA) in 1\% (wt/vol) BSA in PBS and incubated in a humidity chamber for $60 \mathrm{~min}$. Binding sites were labelled with biotin-conjugated rabbit anti-goat IgG antibody followed by the streptavidin-HRP. NC slides, where primary antibody was replaced with rabbit IgG, were also performed.

\section{RNA extraction and $q R T-P C R$}

RNA extraction and qRT-PCR were performed as previously described (Lim et al. 2013a). Briefly, total RNA was extracted from cells using the TRIsure reagent according to manufacturer's instructions (Bioline, Alexandria, NSW, Australia). RNA concentration and purity were measured using a NanoDrop ND1000 Spectrophotometer (Thermo Fisher Scientific). RNA quality was determined via the $A_{260}: A_{280}$ ratio. RNA was converted to cDNA using the Tetro cDNA Synthesis Kit (Bioline) according to the manufacturer's instructions. The CDNA was diluted 50-fold, and $4 \mu$ of this was used to perform RT-PCR using the SensiFAST SYBR NO-ROX Kit (Bioline) and $100 \mathrm{nM}$ of pre-designed and validated QuantiTect primers (Qiagen). The RT-PCR was performed using the CFX384 RealTime PCR detection system (Bio-Rad Laboratories). Average gene $C t$ values were normalised to the average $\beta$-actin $C t$ values of the same cDNA sample. Of note, there was no effect of experimental treatment on $\beta$-actin gene expression. Fold differences were determined using the comparative $C t$ method.

\section{Western blotting}

Extraction of cytoplasmic and nuclear protein by western blotting was performed as previously described (Lim et al. $2013 b$ ). Forty micrograms of protein was separated onto $10 \%$ 
polyacrylamide gels (Bio-Rad Laboratories) and transferred to PVDF. The blots were incubated with $0.8 \mu \mathrm{g} / \mathrm{ml}$ rabbit polyclonal anti-KLF5, \#GTX103289 (GeneTex, Inc.) diluted in blocking buffer (5\% skimmed milk in TBS with $0.05 \%$ Tween-20) for $16 \mathrm{~h}$ at $4{ }^{\circ} \mathrm{C}$. The membranes were viewed and analysed using the ChemiDoc XRS system (Bio-Rad Laboratories). Semi-quantitative analysis of the relative density of the bands in western blots was performed using Quantity One 4.2.1 image analysis software (Bio-Rad Laboratories). The data were normalised to $\beta$-actin or Ponceau $S$ staining as previously described (Lim et al. 2013b). For data normalisation, a section of the Ponceau S stained membrane was chosen. Notably, the section chosen was one that did not show variation with labour status.

\section{Cytokine and prostaglandin assays}

The release of IL6 and IL8 was performed using CytoSet sandwich ELISA according to the manufacturer's instructions (Life Technologies). The limit of detection of the IL6 and IL8 assays was 16 and $12 \mathrm{pg} / \mathrm{ml}$ respectively. The release of $\mathrm{PGE}_{2}$ and $\mathrm{PGF}_{2 \alpha}$ into the incubation medium was assayed using a commercially available competitive enzyme immunoassay kit according to the manufacturer's specifications (Kookaburra Kits from Sapphire Bioscience, Waterloo, NSW, Australia). The limit of detection of the $\mathrm{PGE}_{2}$ and $\mathrm{PGF}_{2 \alpha}$ assays was 16 and $60 \mathrm{pg} / \mathrm{ml}$ respectively. For all assays, the interassay and intraassay coefficients of variation were $<10 \%$.

\section{Statistical analysis}

Statistics was performed on the normalised data unless otherwise specified. All statistical analyses were undertaken using GraphPad Prism (GraphPad Software, La Jolla, CA, USA). For data on the effect of human labour on KLF5 expression in foetal membranes and myometrium, unpaired Student's $t$-test was used to assess statistical significance between normally distributed data; otherwise, the non-parametric MannWhitney $U$ was used. For assessing effect of KLF5 siRNA on basal expression of pro-inflammatory cytokines, a one-sample t-test, against the constant of 1, was used. For assessing effect of KLF5 siRNA on IL $\beta-$, poly(I:C)-, flagellin- induced proinflammatory cytokines; on COX2-prostaglandin pathway and on NFkB p65 transcriptional activity the homogeneity of data was assessed by Bartlett's test, and when significant, the data were logarithmically transformed before further analysis. The data were analysed by a one-way ANOVA using Fisher's least significant difference post hoc test to allow multiple comparisons between groups. Statistical significance was ascribed to $P$ value $<0.05$. Data were expressed as mean \pm s.E.M., unless otherwise specified.

\section{Results \\ Localisation of KLF5 in foetal membranes and myometrium}

Immunohistochemistry was performed on term nonlabouring foetal membranes and myometrium to identify
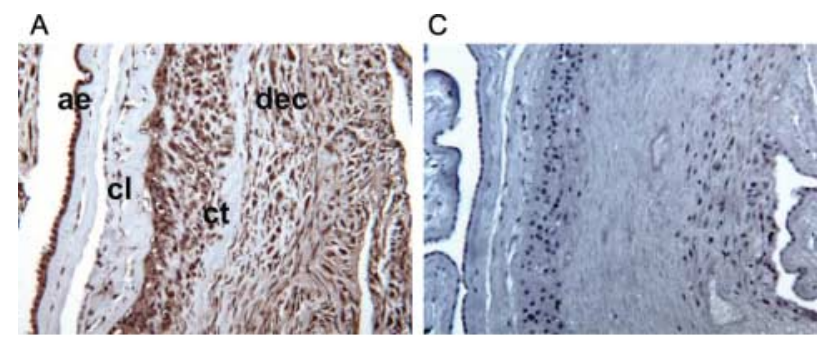

B

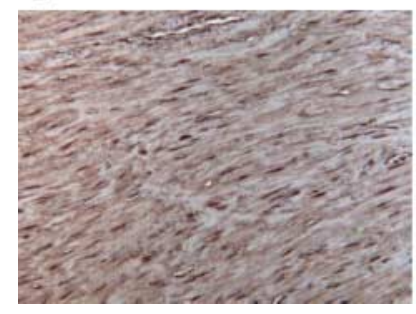

D

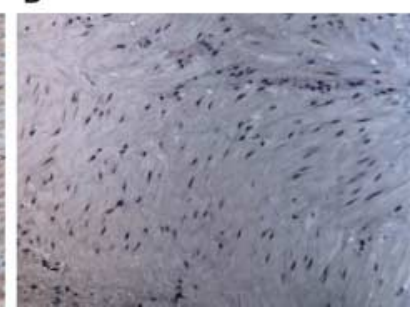

Figure 1 Localisation of KLF5 in term foetal membranes and myometrium. KLF5 expression in human term (A) foetal membranes and (B) myometrium. Negative control for (C) foetal membranes and (D) myometriumis also displayed. ae, amniotic epithelium; $\mathrm{cl}$, connective tissue layer; ct, cytotrophoblast layer; dec, decidua. Original magnification $\times 100$.

the cellular localisation of KLF5 (Fig. 1). In foetal membranes, positive cytoplasmic and nuclear KLF5 expression was detected in amnion epithelial cells, cytotrophoblast cells and decidua (Fig. 1A). In addition, some KLF5 expression was also observed in the fibroblast cells of the connective tissue layer. In myometrium, positive KLF5 cytoplasmic and nuclear staining was detected in the smooth muscle fibres (Fig. 1C). There was no staining present in the NC for foetal membranes (Fig. 1B) or myometrium (Fig. 1D).

\section{Effect term and preterm labour on KLF5 expression in human foetal membranes and myometrium}

The next aim of this study was to determine the effect of human labour on KLF5 nuclear protein expression in foetal membranes and myometrium. Foetal membranes were obtained at term Caesarean section in the absence of labour (term no labour; $n=6$ patients) and after spontaneous labour and membrane rupture (term after labour; $n=6$ patients). To determine the effect of spontaneous preterm birth (without histological chorioamnionitis) on KLF5 expression, foetal membranes were obtained from women at preterm Caesarean section with no labour (preterm no labour; $n=6$ patients), and after spontaneous preterm labour and normal vaginal delivery (preterm after labour; $n=6$ patients). Myometrium was obtained at term Caesarean section in the absence of labour (term no labour; $n=6$ patients) and after spontaneous labour onset (term in labour; $n=6$ patients). 

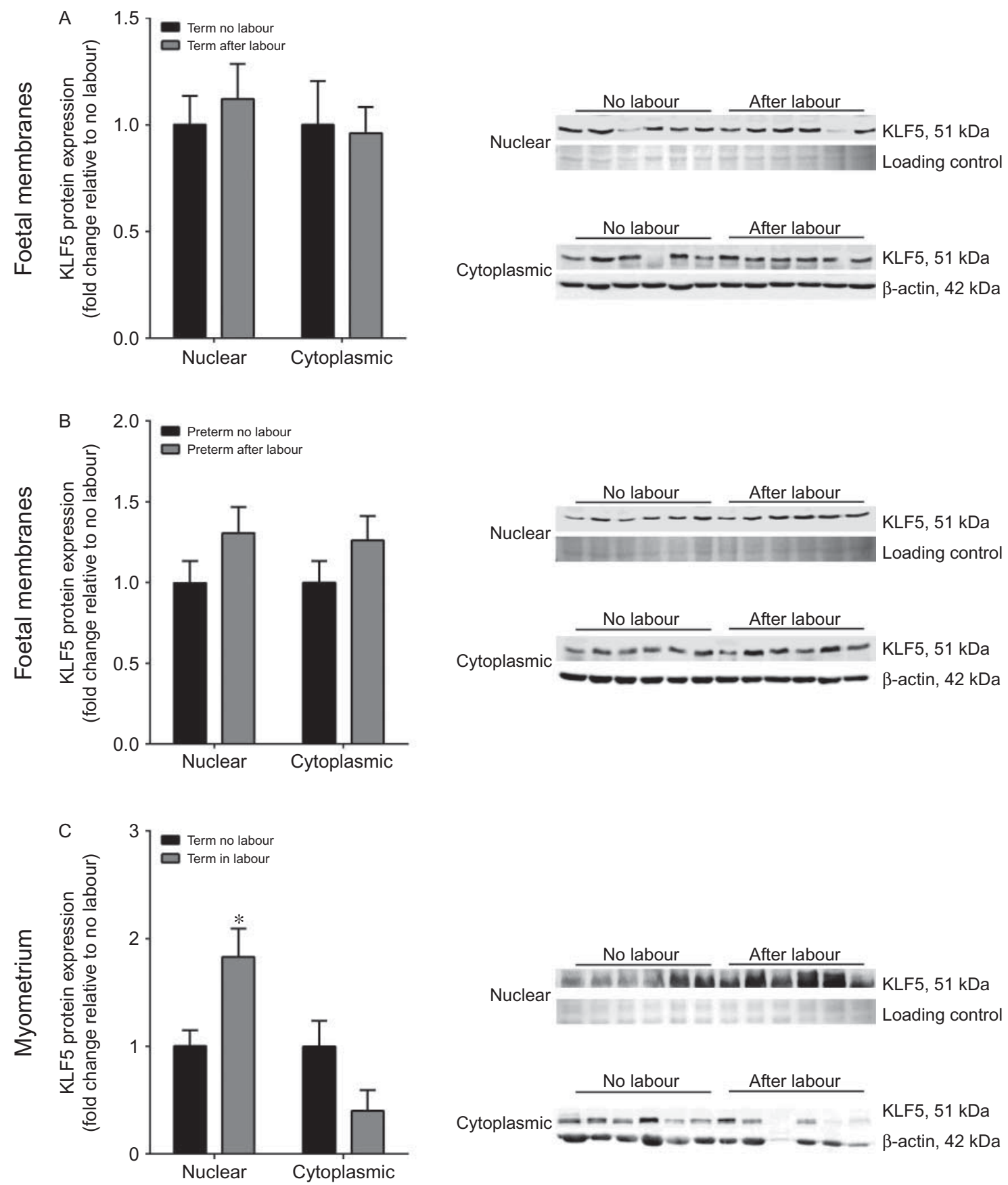

Figure 2 Effect of human labour on KLF5 expression in foetal membranes and myometrium. (A) Human foetal membranes were obtained from women not in labour at term Caesarean section and women after term spontaneous labour onset and delivery ( $n=6$ patients/group). (B) Human foetal membranes were obtained from women not in labour at preterm Caesarean section and women after preterm spontaneous labour onset and delivery ( $n=6$ patients/group). (C) Human myometrium was obtained from non-labouring and labouring women at term Caesarean section ( $n=6$ patients/group). (A, B and C) Nuclear and cytoplasmic protein expression of KLF5 was analysed by western blotting analysis. KLF5 protein expression was normalised to either loading control (Ponceau S) or $\beta$-actin and the fold change was calculated relative to the no labour group. Data are displayed as mean \pm s.E.M. ${ }^{*} P<0.05$ vs no labour (Student's $t$-test). The western blot from the six patients per group is also shown.

In foetal membranes, KLF5 cytoplasmic and nuclear protein expression was similar between nonlabouring and labouring tissues at both term (Fig. 2A) and preterm (Fig. 2B). On the other hand, in myometrium, KLF5 nuclear protein expression was significantly higher in labouring myometrium when compared with non-labouring samples (Fig. 2C). Although cytoplasmic KLF5 was lower in labouring myometrium, this did not reach statistical significance $(P=0.06)$. 


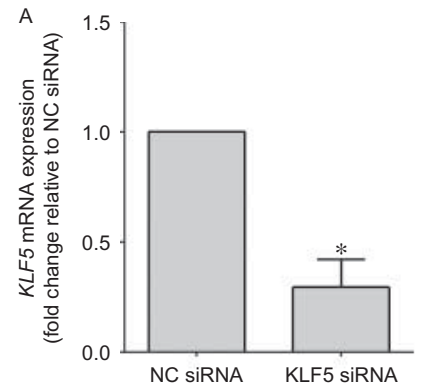

B
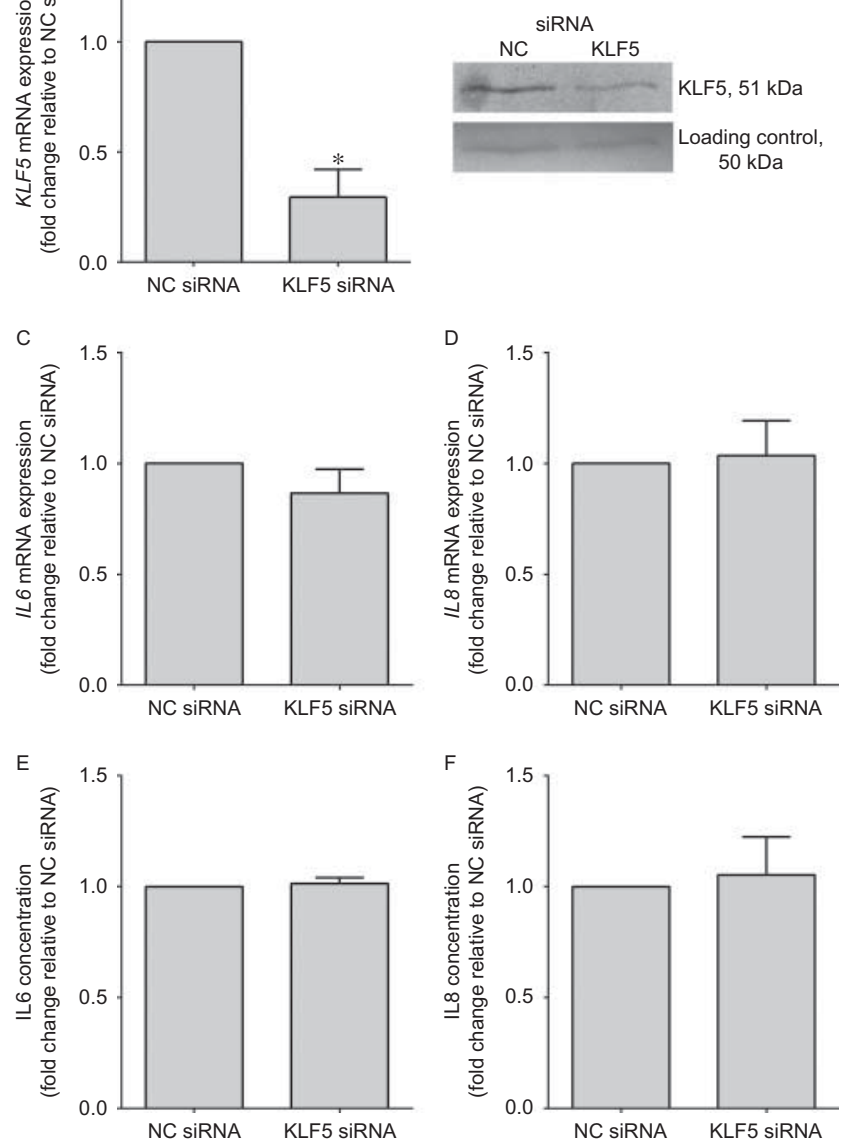

Figure 3 Effect of KLF5 siRNA on basal expression of pro-inflammatory cytokines. Human primary myometrial cells were transfected with or without $200 \mathrm{nM} \mathrm{KLF} 5$ or NC siRNA for $48 \mathrm{~h}$ ( $n=3$ patients). (A, C and D) KLF5, IL6 and IL8 gene expression was analysed by qRT-PCR. Gene expression was normalised to $\beta$-actin mRNA expression and the fold change was calculated relative to the NC siRNA-transfected cells. Data are displayed as mean \pm S.E.M. ${ }^{*} P<0.05$ vs NC siRNA (one-sample $t$-test). (B) Representative western blot images demonstrating KLF5 protein expression. Ponceau S staining was used as loading control. ( $E$ and $F$ ) The incubation medium was assayed for concentration of IL 6 and IL 8 by ELISA. The fold change was calculated relative to NC siRNA-transfected cells. Data displayed as mean \pm s.E.M.

\section{Effect of KLF5 siRNA on pro-inflammatory cytokines in primary myometrium cells}

Having shown that human term labour increases KLF5 expression in myometrium; the next aim of this study was to determine the effect of KLF5 knockdown using siRNA on pro-labour mediators. For these studies, primary myometrial cells isolated from fresh myometrial tissue were used. The efficacy of transfection was analysed by qRT-PCR and western blotting and the data presented in Fig. $3 \mathrm{~A}$ and $\mathrm{B}$; both the gene and protein expression of KLF5 were decreased in KLF5 siRNA transfected cells when compared with NC siRNA transfected cells. Also presented in Fig. 3 is the effect of KLF5 siRNA knockdown on IL6 and IL8 mRNA expression and release under basal conditions. There was no effect of KLF5 siRNA knockdown on basal mRNA expression (Fig. 3C and E) or release (Fig. 3D and F) of IL6 and IL8.

For subsequent experiments, after siRNA transfection, cells were treated with the pro-inflammatory cytokine $I L 1 \beta$, the viral dsRNA analogue poly $(\mathrm{I}: \mathrm{C})$ and the bacterial product flagellin to mimic preterm labour in order to define the relative importance of KLF5 in the expression of pro-inflammatory cytokines and prostaglandin synthesis. Figure 4 demonstrates the effect of siRNA knockdown of KLF5 on $I L 1 \beta$-induced gene expression and secretion of pro-inflammatory cytokines. When compared with basal NC siRNA, there was a significant increase in both the mRNA expression (Fig. 4A and C) and release (Fig. 4B and D) of IL6 and IL8. However, in cells deficient in KLF5, this increase in cytokine expression and secretion was significantly reduced.

The effect of KLF5 siRNA knockdown on the expression and release of pro-inflammatory cytokines in the presence of poly $(\mathrm{l}: \mathrm{C})$ is shown in Fig. 5. In NC siRNA transfected cells, IL6 and IL 8 mRNA expression
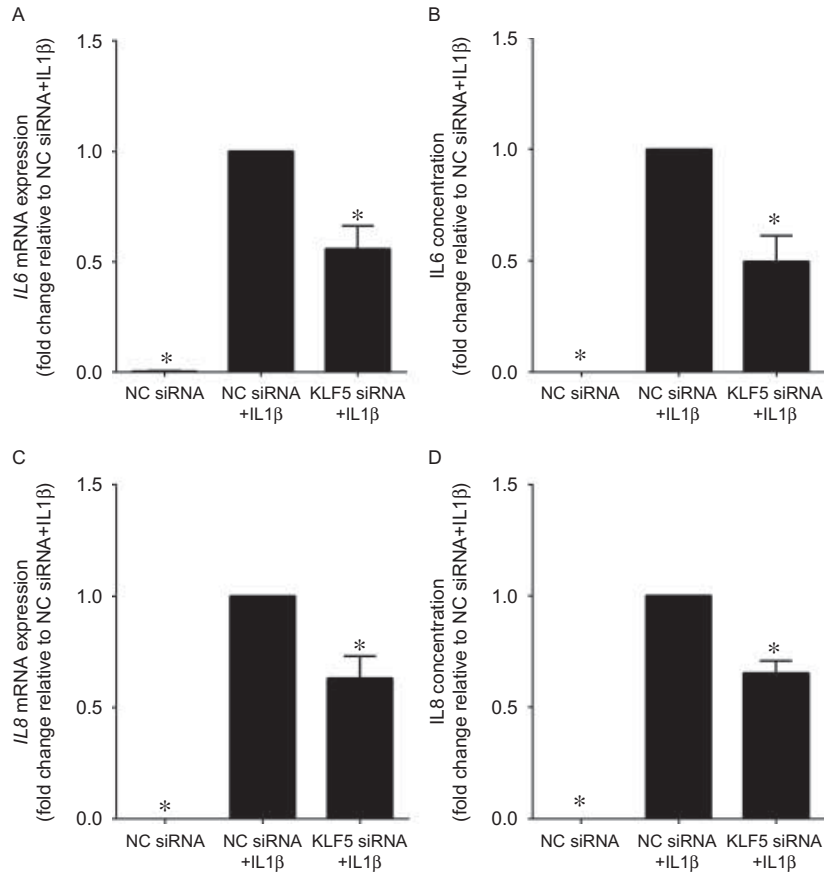

Figure 4 Effect of KLF5 siRNA on IL $\beta$-induced pro-inflammatory cytokines. Human primary myometrial cells were transfected with or without $200 \mathrm{nM} \mathrm{KLF} 5$ or NC siRNA $48 \mathrm{~h}$ and then treated with $1 \mathrm{ng} / \mathrm{ml}$ IL1 $\beta$ for an additional $24 \mathrm{~h}$ ( $n=5$ patients). (A and C) Gene expression for IL6 and IL 8 was analysed by qRT-PCR. Gene expression was normalised to $\beta$-actin mRNA expression and the fold change was calculated relative to IL1 $\beta$-stimulated NC siRNA-transfected cells. Data displayed as mean \pm s.E.M. ${ }^{*} P<0.05$ vs IL $1 \beta$-stimulated NC siRNAtransfected cells (one-way ANOVA). (B and D) The incubation medium was assayed for concentration of IL6 and IL 8 by ELISA. The fold change was calculated relative to IL1 $\beta$-stimulated NC siRNA-transfected cells. Data displayed as mean \pm s.E.M. ${ }^{*} P<0.05$ vs IL1 $\beta$-stimulated NC siRNA-transfected cells (one-way ANOVA). 

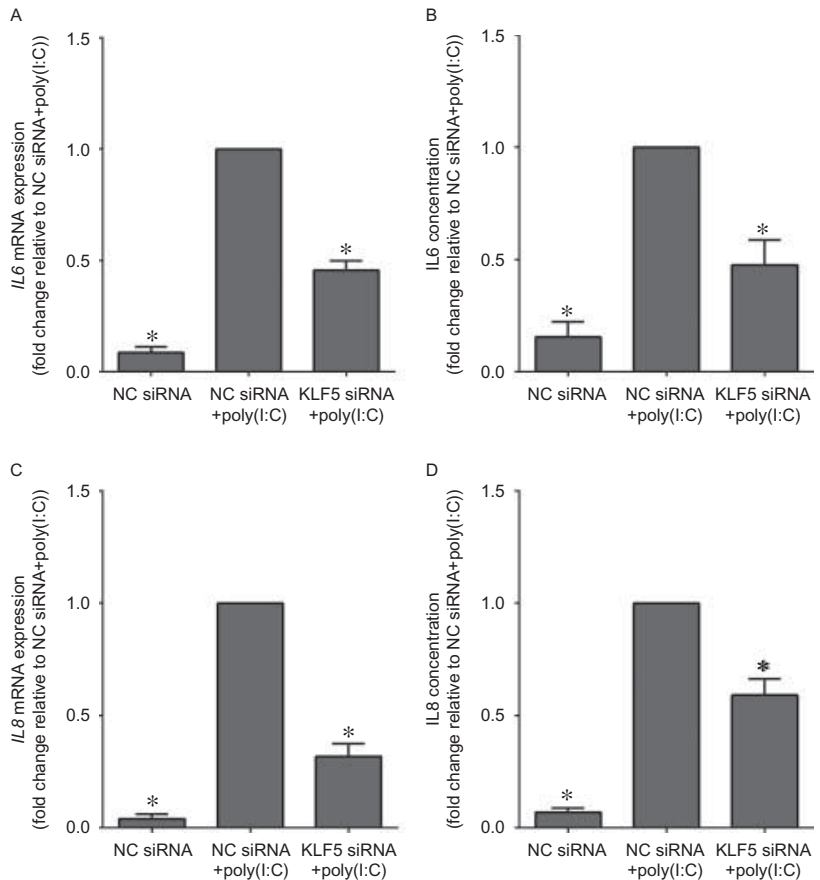

Figure 5 Effect of KLF5 siRNA on poly(l:C)-induced pro-inflammatory cytokines. Human primary myometrial cells were transfected with or without $200 \mathrm{nM} \mathrm{KLF} 5$ or NC siRNA $48 \mathrm{~h}$ and then treated with $5 \mu \mathrm{g} / \mathrm{ml}$ poly(I:C) for an additional $24 \mathrm{~h}$ ( $n=5$ patients). (A and C) Gene expression for IL6 and IL 8 was analysed by qRT-PCR. Gene expression was normalised to $\beta$-actin mRNA expression and the fold change was calculated relative to poly(I:C)-stimulated NC siRNA-transfected cells. Data displayed as mean \pm s.E.M. ${ }^{*} P<0.05$ vs poly(I:C)-stimulated NC siRNA-transfected cells (one-way ANOVA). (B and D)The incubation medium was assayed for concentration of IL6 and IL8 by ELISA. The fold change was calculated relative to poly(l:C)-stimulated NC siRNA-transfected cells. Data displayed as mean \pm S.E.M. ${ }^{*} P<0.05$ vs poly(l:C)-stimulated NC siRNA-transfected cells (one-way ANOVA).

(Fig. 5A and C) and release (Fig. 5B and D) was significantly augmented by poly $(\mathrm{l}: \mathrm{C})$. This increase in poly(I:C)-induced cytokine production was significantly reduced in cells transfected with KLF5 siRNA.

The effect of KLF5 siRNA silencing on the expression and secretion of pro-inflammatory cytokines in the presence of flagellin is depicted in Fig. 6. As expected, in NC siRNA transfected myometrial cells, flagellin induced a significant increase in IL6 and IL8 mRNA expression (Fig. 6A and C) and release (Fig. 6B and D). The effect of KLF5 silencing was a significant decrease in flagellininduced cytokine gene expression and secretion.

\section{Effect of KLF5 siRNA on the COX2-prostaglandin pathway in primary myometrium cells}

The effect of KLF5 silencing on the COX-prostaglandin pathway in the presence of IL1 $\beta, T N F \alpha$ or poly $(\mathrm{I}: \mathrm{C})$ was also assessed and the data presented in Fig. 7. As expected, in NC siRNA transfected myometrial cells, treatment with IL1 $\beta$ (Fig. 7A), poly(l:C) (Fig. 7D) or flagellin (Fig. 7E) induced a significant increase in COX2
mRNA expression. Likewise, the release of $\mathrm{PGE}_{2}$ and $\mathrm{PGF}_{2 \alpha}$ was significantly augmented by IL $1 \beta$ in NC siRNA transfected cells (Fig. 7B and C). The concentration of prostaglandins was below the sensitivity of the curve for poly(I:C)- or flagellin-stimulated primary human myometrial cells. The effect of KLF5 silencing was a significant decrease in IL $\beta$-induced COX2 gene expression, and $\mathrm{PGE}_{2}$ and $\mathrm{PGF}_{2 \alpha}$ release (Fig. $7 \mathrm{~A}, \mathrm{~B}$ and C). Similarly, KLF5 knockout was associated with a significant decrease in poly(l:C)- and flagellin-induced COX2 gene expression (Fig. 7D and E). Of note, there was no effect of IL1 $\beta$, poly(I:C), flagellin, or KLF5 siRNA on COX1 mRNA expression (data not shown).

\section{Silencing of KLF5 represses NFKB p65 transcriptional activity}

To determine whether KLF5 regulates pro-labour mediators in primary myometrial cells through $\mathrm{NF \kappa B}$, the effect of $K L F 5$ gene silencing on NFKB transcriptional activity was determined using a luciferase activity assays. As shown in Fig. 8, treatment with IL1 $\beta$ (Fig. 8A), poly(I:C)
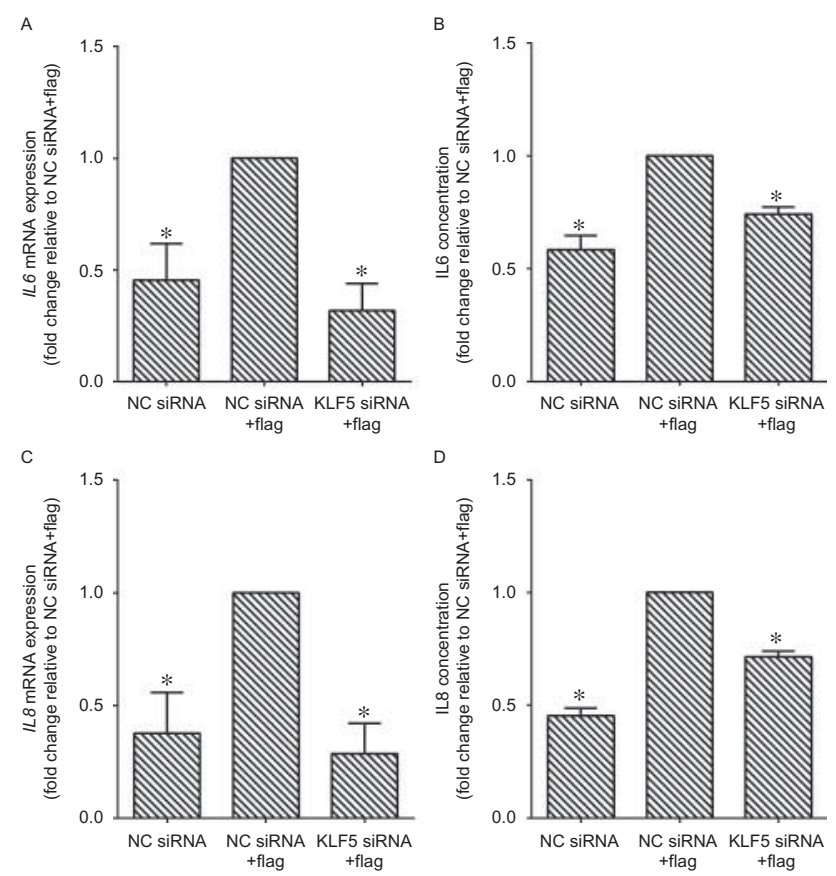

Figure 6 Effect of KLF5 siRNA on flagellin-induced pro-inflammatory cytokines. Human primary myometrial cells were transfected with or without $200 \mathrm{nM} \mathrm{KLF} 5$ or NC siRNA $48 \mathrm{~h}$ and then treated with $1 \mu \mathrm{g} / \mathrm{ml}$ flagellin (flag) for an additional $24 \mathrm{~h}$ ( $n=5$ patients). (A and C) Gene expression for IL 6 and IL 8 was analysed by qRT-PCR. Gene expression was normalised to $\beta$-actin mRNA expression and the fold change was calculated relative to flag-stimulated NC siRNA-transfected cells. Data displayed as mean \pm s.E.M. ${ }^{*} P<0.05$ vs flag-stimulated NC siRNAtransfected cells (one-way ANOVA). (B and D) The incubation medium was assayed for concentration of IL 6 and IL 8 by ELISA. The fold change was calculated relative to flag-stimulated NC siRNA-transfected cells. Data displayed as mean \pm s.E.M. ${ }^{*} P<0.05$ vs flag-stimulated NC siRNA-transfected cells (one-way ANOVA). 

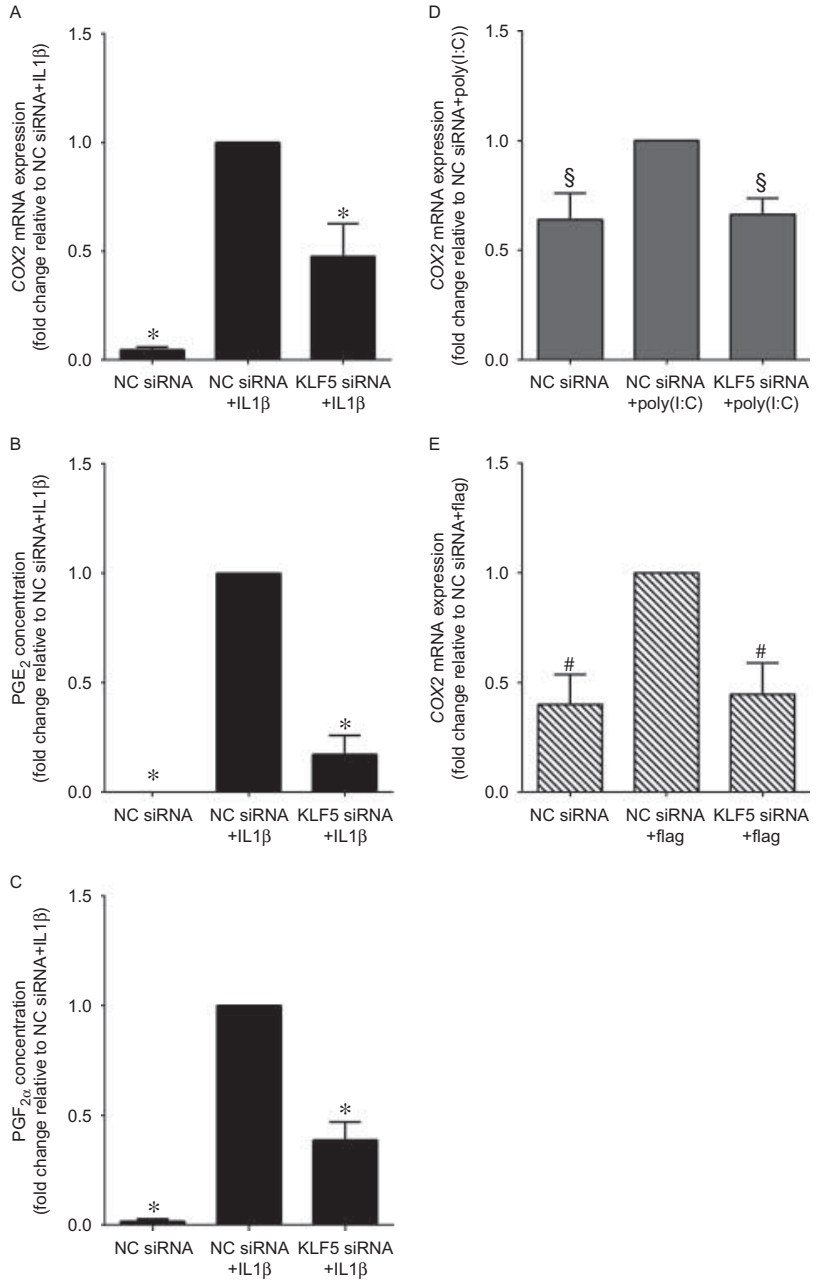

Figure 7 Effect of KLF5 siRNA on COX2-prostaglandin pathway. Human primary myometrial cells were transfected with or without $200 \mathrm{nM} \mathrm{KLF5}$ or NC siRNA $48 \mathrm{~h}$ and then treated with (A, B and C) $1 \mathrm{ng} / \mathrm{ml} \mathrm{IL1 \beta}$, (D) $5 \mu \mathrm{g} / \mathrm{ml}$ poly(l:C) or (E) $1 \mu \mathrm{g} / \mathrm{ml}$ flagellin (flag) for an additional $24 \mathrm{~h}$ ( $n=5$ patients). (A, D and E) Gene expression for COX2 was analysed by qRT-PCR. Gene expression was normalised to $\beta$-actin mRNA expression and the fold change was calculated relative to IL1 $\beta$-, poly(I:C)- or flag-stimulated NC siRNA-transfected cells. Data displayed as mean \pm S.E.M. $* P<0.05$ vs IL $1 \beta$-stimulated NC siRNAtransfected cells (one-way ANOVA); ${ }^{\S} P<0.05$ vs poly(I:C)-stimulated NC siRNA-transfected cells (one-way ANOVA) and ${ }^{\#} P<0.05$ vs flagstimulated NC siRNA-transfected cells (one-way ANOVA). (B and C) The incubation medium was assayed for the concentration of $\mathrm{PGE}_{2}$ and $\mathrm{PGF}_{2 \alpha}$ release by EIA. Data displayed as mean \pm S.E.M. ${ }^{*} P<0.05$ vS IL1 $\beta$-stimulated NC siRNA-transfected cells (one-way ANOVA).

(Fig. 8B) or flagellin (Fig. 8C) significantly increased NFкB p65 luciferase activity in NC siRNA-transfected myometrial cells. However, luciferase activity was significantly decreased in KLF5 siRNA-transfected cells.

\section{Discussion}

The novel findings of this study are KLF5 expression is higher in term labouring myometrium when compared with term non-labouring myometrium. Moreover, loss-of-function studies using siRNA in primary myometrial cells revealed that KLF5 is required for the expression and secretion of pro-inflammatory and prolabour mediators in the presence of mediators of preterm birth. Specifically, in cells transfected with KLF5 siRNA, there was a significant decrease in IL1 $\beta$-, flagellin- and poly(I:C)-stimulated expression and secretion of proinflammatory cytokines, and COX2 expression and prostaglandin release. Furthermore, a luciferase assay also demonstrated a significant decrease in NFкB p65 transcriptional activity in KLF5 siRNA-transfected cells, suggesting that KLF5 may mediate its pro-inflammatory effects via the NFKB pathway.

Human labour is considered an inflammatory response as an influx of leukocytes into the myometrium and cervix increases the production of pro-inflammatory cytokines IL $1 \beta$ and $T N F \alpha$ in these tissues as well as foetal membranes (Osman et al. 2003, Romero et al. 2006, Bollapragada et al. 2009). Contributing to the onset of labour, these pro-inflammatory cytokines can increase the production of pro-inflammatory cytokines and chemokines; promote the production of prostaglandins via COX2, mediators of uterine contractions; and MMPs,
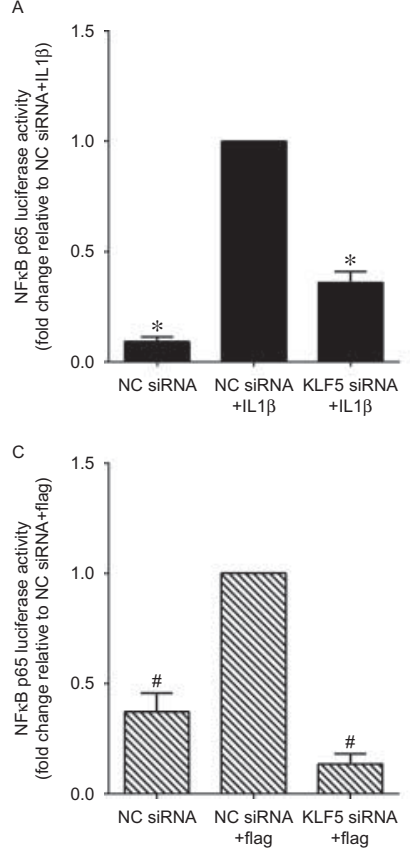

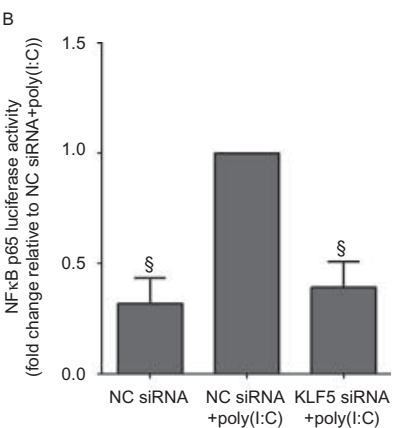

Figure 8 Effect of KLF5 siRNA on NFKB p65 transcriptional activity. Human myometrial cells were transfected with $0.1 \mu \mathrm{g} N F \kappa B$ reporter construct. After $6 \mathrm{~h}$, cells were transfected with $200 \mathrm{nM} \mathrm{KLF} 5$ or NC siRNA for $48 \mathrm{~h}$, then treated with (A) $1 \mathrm{ng} / \mathrm{ml}$ IL $1 \beta$, (B) $5 \mu \mathrm{g} / \mathrm{ml}$ poly(l:C) or (C) $1 \mu \mathrm{g} / \mathrm{ml}$ flagellin (flag) for an additional $24 \mathrm{~h}$ ( $n=5$ patients). Promoter activity (normalised with Renilla expression) is expressed as a ratio of luciferase activity of IL1 $\beta-$, poly(I:C)- or flag-stimulated NC siRNA-transfected cells. Each bar represents the mean \pm s.E.M. $* P<0.05$ vs IL1 $\beta$ stimulated NC siRNA-transfected cells (one-way ANOVA); ${ }^{\S} P<0.05$ vs poly(l:C)-stimulated NC siRNA-transfected cells (one-way ANOVA) and ${ }^{\#} P<0.05$ vs flag-stimulated NC siRNA-transfected cells (one-way ANOVA). 
which instigate cervical ripening and foetal membrane rupture, events culminating in successful labour and delivery (Fata et al. 2000, Bowen et al. 2002, Keelan et al. 2003, Lappas \& Rice 2004, Christiaens et al. 2008). While nuclear KLF5 expression was increased in myometrium with spontaneous term labour, there was no change in KLF5 expression in foetal membranes after spontaneous labour and delivery, at term or preterm. It may be that KLF5 acts in the myometrium during labour to induce uterine contractions, upstream from events that lead to rupture of membranes.

It is possible that increased KLF5 expression in term labouring myometrium may be a consequence of the processes of labour. Indeed, it has been shown that TNF $\alpha$ induces KLF5 expression in human umbilical vein endothelial cells, venous smooth muscle cells and intestinal epithelial cells (Bafford et al. 2006, Kumekawa et al. 2008). Whether KLF5 expression is also increased in labouring myometrium from preterm deliveries with or without infection is not known and could not be determined due to lack of suitable samples. However, bacterial endotoxin LPS has been shown to induce KLF5 expression in vitro (Chanchevalap et al. 2006, Chen et al. 2014) and in vivo (Chen et al. 2014). Likewise, the Gram-negative, microaerophilic bacterium Helicobacter pylori promotes the expression of KLF5 in human gastric epithelial cells (Noto et al. 2013).

Term and preterm labour share the common terminal pathway of labour that includes increased myometrial contractility, cervical ripening and decidual/membrane activation (Romero et al. 2006). Term labour is the result of physiological activation of this pathway, while preterm labour is due to pathological insults (Romero et al. 2006). There appears to be a causal role for IL $1 \beta$ in the processes of parturition; there is elevated expression of IL1 $\beta$ in the third trimester during normal pregnancies without signs of infection (Elliott et al. 2001) as well as in pregnancies that display infection and in preterm deliveries (Goldenberg et al. 2000, Menon \& Fortunato 2004, Farina \& Winkelman 2005). Intrauterine infection caused by bacteria is a common and important mechanism that leads to preterm birth (Goldenberg et al. 2000). Bacterial products, such as flagellin which is isolated from both Gram-positive and Gram-negative bacteria, stimulate the production of pro-inflammatory cytokines and prostaglandins, leading to myometrial contractions and thus preterm labour (Schaefer et al. 2004, Herbst-Kralovetz et al. 2008, Lim et al. 2014). Associations between viral infections and chorioamnionitis and/or spontaneous preterm birth have been also reported (Gomez et al. 2008, Tsekoura et al. 2010). Furthermore, the viral dsRNA analogue poly $(\mathrm{I}: \mathrm{C})$ induces pro-inflammatory cytokines in foetal membranes (Bakaysa et al. 2014). It was thus of interest to determine if KLF5 regulates pro-inflammatory and pro-labour mediators in the presence of IL1 $\beta$, flagellin and the poly $(\mathrm{l}: \mathrm{C})$ in human myometrium.
Loss-of-function studies revealed that KLF5 has a pro-inflammatory and pro-labour role in human myometrium. Specifically, KLF5 silencing attenuated IL1 $\beta$ stimulated expression of pro-inflammatory cytokines IL6 and IL8, COX2 mRNA expression and release of prostaglandins $\mathrm{PGE}_{2}$ and $\mathrm{PGF}_{2 \alpha}$. In addition, flagellinand poly(I:C)-induced IL6 and IL8 mRNA expression was also significantly reduced in KLF5 knockout cells. Concurrent with these findings, knockdown of KLF5 by siRNA inhibits TNF $\alpha$-induced MCP1 expression in endothelial cells (Kumekawa et al. 2008), LPS-induced TNF $\alpha$ and IL6 in intestinal epithelial cells (Chanchevalap et al. 2006); and microsomal PGE $_{2}$ synthase 1 (mPGES1) mRNA and protein expression and subsequent $\mathrm{PGE}_{2}$ synthesis in breast cancer cells (Xia et al. 2013). In vivo, epithelial COX2 expression is absent with loss of KLF5 (Sun et al. 2012); KLF5 heterozygous knockout mice show an attenuated induction of hyperproliferative responses after bacterial infection (McConnell et al. 2008) and KLF5 haploinsufficient $\left(\mathrm{KIf5}^{+/-}\right)$mice are protected from renal injury and inflammation induced by UUO (Fujiu et al. 2011). The zinc finger E-box binding homeobox protein ZEB2 is increased in KLF5 deficient embryonic stem cells (Parisi et al. 2010). Interestingly, in uterine tissues, the ZEB1 and ZEB2 proteins, which are downregulated during human labour and in mouse models of preterm labour (Renthal et al. 2010), have been shown to regulate uterine quiescence and contractility during pregnancy and labour (Renthal et al. 2010).

It is now well established that the pro-inflammatory nuclear transcription factor, $N F \kappa B$, plays a crucial role in the processes of human labour and delivery (Belt et al. 1999, Lappas et al. 2002, 2003, 2004, 2006, Lappas \& Rice 2007). NFKB has been shown to regulate the expression of numerous pro-labour genes including IL6, IL8 and COX2 in the presence of infection or inflammation (Belt et al. 1999, Lappas et al. 2002, 2003, 2004, 2006, Lappas \& Rice 2007, Bakaysa et al. 2014). Studies in non-gestational tissues demonstrate that $\mathrm{NF} \kappa \mathrm{B}$ is required for KLF5 signalling. For example, in intestinal epithelial cells, knockdown of KLF5 by siRNA reduces the expression of p50 and p65 subunits of $N F \kappa B$ in response to LPS (Chanchevalap et al. 2006). Thus, in order to determine if $\mathrm{NF \kappa B}$ plays a role in the proinflammatory actions of KLF5 in response to IL1 $\beta$, flagellin or poly(I:C), a luciferase assay was performed. As expected, the pro-inflammatory cytokine IL1 $\beta$, the bacterial product flagellin and the viral dsRNA analogue poly $(\mathrm{I}: \mathrm{C})$ induced NFKB transcriptional activity in NC siRNA transfected primary myometrial cells. Notably, in cells transfected with KLF5 siRNA, there was a significant decrease in $\mathrm{NF \kappa B}$ transcriptional activity in the presence of IL1 $\beta$, flagellin or poly $(\mathrm{I}: \mathrm{C})$, suggesting that KLF5 may be exerting its pro-inflammatory and pro-labour actions via NFKB. These finding suggests that KLF5 is an important transcription factor required for NFKB promoter activity. That is, KLF5 may interact with 
the NFKB promoter in myometrial cells upon IL1 $\beta$, flagellin or poly(I:C) stimulation. Indeed, KLF5 has also been shown to directly interact with NFKB in epidermal epithelial cells (Sur et al. 2002).

Members of the KLF family of transcription factors share a high degree of sequence homology in their zincfinger regions; however their non-DNA binding portions are diverse in composition and thus function (Bieker 2001). Several of the 17 mammalian KLF proteins have been implicated in inflammation, with both pro- and anti-inflammatory actions reported. For example, overexpression of KLF4 mediates pro-inflammatory signalling in macrophages (Feinberg et al. 2005, Liu et al. 2012); overexpression of KLF2 downregulates pneumococci-induced $N F_{K} B$-dependent gene expression and IL8 release; siRNA silencing of KLF2 provoked an enhanced inflammatory response (Zahlten et al. 2010); and mice with systemic and smooth muscle-specific deficiency of KLF15 exhibit aggressive inflammatory vasculopathy (Lu et al. 2013). On the other hand, overexpression of KLF6 in HEK293 cells enhances TNF $\alpha$ and IL1 $\beta$-induced activation of $N F_{K} B$ and transcription of downstream genes; knockdown of KLF6 had the opposite effects (Zhang et al. 2014). In cultured 3T3-L1 adipocytes, treatment with TNF $\alpha$ significantly reduced the mRNA levels of KLF9 and KLF15 (Enomoto et al. 2013). Thus, it would also be of interest to elucidate the role that other KLF family members play in human myometrium.

In conclusion, KLF5 has a pro-inflammatory role in human myometrium. KLF5 expression was increased in labouring term myometrium. Furthermore, silencing of KLF5 in myometrial cells decreased inflammationinduced expression of pro-inflammatory cytokines, COX2 mRNA expression and subsequent prostaglandin release. In addition, bacterial and viral infection-induced pro-inflammatory cytokine release was also significantly reduced in KLF5 siRNA knockout cells. These findings are of significance given the central role of these mediators in the terminal processes of human preterm labour and delivery (Bowen et al. 2002, Keelan et al. 2003, Lappas \& Rice 2004, Christiaens et al. 2008). Further studies are required to further elucidate the role of KLF5 in the processes of human labour and delivery and its potential as a therapeutic target for the treatment of inflammationand/or infection-induced preterm birth.

\section{Declaration of interest}

The authors declare that there is no conflict of interest that could be perceived as prejudicing the impartiality of the research reported.

\section{Funding}

Associate Professor M Lappas is supported by a Career Development Fellowship from the National Health and Medical Research Council (NHMRC; grant number
1047025). Additional funding was provided by the Medical Research Foundation for Women and Babies and the Mercy Research Foundation.

\section{Acknowledgements}

Dr Ratana Lim and Gillian Barker (Obstetrics, Nutrition and Endocrinology Group, Department of Obstetrics and Gynaecology, University of Melbourne) are thanked for their technical assistance. The clinical research midwives Genevieve Christophers, Gabrielle Pell and Rachel Murdoch are gratefully acknowledged for assistance with sample collection. The Obstetrics and Midwifery staffs of the Mercy Hospital for Women are also thanked for their co-operation.

\section{References}

Aizawa K, Suzuki T, Kada N, Ishihara A, Kawai-Kowase K, Matsumura T, Sasaki K, Munemasa Y, Manabe I, Kurabayashi M et al. 2004 Regulation of platelet-derived growth factor-A chain by Kruppel-like factor 5: new pathway of cooperative activation with nuclear factor- $\kappa$ B. Journal of Biological Chemistry 279 70-76. (doi:10.1074/jbc.M3066 21200)

Bafford R, Sui XX, Wang G \& Conte M 2006 Angiotensin II and tumor necrosis factor- $\alpha$ upregulate survivin and Kruppel-like factor 5 in smooth muscle cells: potential relevance to vein graft hyperplasia. Surgery 140 289-296. (doi:10.1016/j.surg.2006.04.004)

Bai Q, Assou S, Haouzi D, Ramirez JM, Monzo C, Becker F, GerbalChaloin S, Hamamah S \& De Vos J 2012 Dissecting the first transcriptional divergence during human embryonic development. Stem Cell Reviews 8 150-162. (doi:10.1007/s12015-011-9301-3)

Bakaysa SL, Potter JA, Hoang M, Han CS, Guller S, Norwitz ER \& Abrahams VM 2014 Single- and double-stranded viral RNA generate distinct cytokine and antiviral responses in human fetal membranes. Molecular Human Reproduction 20 701-708. (doi:10.1093/molehr/ gau028)

Belt AR, Baldassare JJ, Molnar M, Romero R \& Hertelendy F 1999 The nuclear transcription factor NF- $\kappa$ B mediates interleukin-1 $\beta$-induced expression of cyclooxygenase-2 in human myometrial cells. American Journal of Obstetrics and Gynecology 181 359-366. (doi:10.1016/ S0002-9378(99)70562-4)

Bieker JJ 2001 Kruppel-like factors: three fingers in many pies. Journal of Biological Chemistry 276 34355-34358. (doi:10.1074/jbc. R100043200)

Black AR, Black JD \& Azizkhan-Clifford J 2001 Sp1 and Kruppel-like factor family of transcription factors in cell growth regulation and cancer. Journal of Cellular Physiology 188 143-160. (doi:10.1002/jcp.1111)

Bollapragada S, Youssef R, Jordan F, Greer I, Norman J \& Nelson S 2009 Term labor is associated with a core inflammatory response in human fetal membranes, myometrium, and cervix. American Journal of Obstetrics and Gynecology 200 104.e1-104.e11. (doi:10.1016/j.ajog. 2008.08.032)

Bowen JM, Chamley L, Keelan JA \& Mitchell MD 2002 Cytokines of the placenta and extra-placental membranes: roles and regulation during human pregnancy and parturition. Placenta 23 257-273. (doi:10.1053/ plac.2001.0782)

Chanchevalap S, Nandan MO, McConnell BB, Charrier L, Merlin D, Katz JP \& Yang VW 2006 Kruppel-like factor 5 is an important mediator for lipopolysaccharide-induced proinflammatory response in intestinal epithelial cells. Nucleic Acids Research 34 1216-1223. (doi:10.1093/ nar/gkl014)

Chen HL, Chong IW, Lee YC, Tsai JR, Yuan SS, Wang HM, Liu WL \& Liu PL 2014 Kruppel-like factor 5 mediates proinflammatory cytokine expression in lipopolysaccharide-induced acute lung injury through upregulation of nuclear factor- $\kappa \mathrm{B}$ phosphorylation in vitro and in vivo. Mediators of Inflammation 2014 281984. (doi:10.1155/2014/281984) 
Christiaens I, Zaragoza DB, Guilbert L, Robertson SA, Mitchell BF \& Olson DM 2008 Inflammatory processes in preterm and term parturition. Journal of Reproductive Immunology 79 50-57. (doi:10.1016/j.jri.2008. 04.002)

Dang DT, Pevsner J \& Yang VW 2000 The biology of the mammalian Kruppel-like family of transcription factors. International Journal of Biochemistry \& Cell Biology 32 1103-1121. (doi:10.1016/S13572725(00)00059-5)

Denison FC, Kelly RW, Calder AA \& Riley SC 1998 Cytokine secretion by human fetal membranes, decidua and placenta at term. Human Reproduction 13 3560-3565. (doi:10.1093/humrep/13.12.3560)

Elliott CL, Loudon JA, Brown N, Slater DM, Bennett PR \& Sullivan MH 2001 IL-1 $\beta$ and IL-8 in human fetal membranes: changes with gestational age, labor, and culture conditions. American Journal of Reproductive Immunology 46 260-267. (doi:10.1034/j.1600-0897.2001.d01-11.x)

Enomoto T, Ohashi K, Shibata R, Kambara T, Uemura Y, Yuasa D, Kataoka Y, Miyabe M, Matsuo K, Joki Y et al. 2013 Transcriptional regulation of an insulin-sensitizing adipokine adipolin/CTRP12 in adipocytes by Kruppel-like factor 15. PLoS ONE 8 e83183. (doi:10. 1371/journal.pone.0083183)

Farina L \& Winkelman C 2005 A review of the role of proinflammatory cytokines in labor and noninfectious preterm labor. Biological Research for Nursing 6 230-238. (doi:10.1177/1099800404271900)

Fata JE, Ho AT, Leco KJ, Moorehead RA \& Khokha R 2000 Cellular turnover and extracellular matrix remodeling in female reproductive tissues: functions of metalloproteinases and their inhibitors. Cellular and Molecular Life Sciences 57 77-95. (doi:10.1007/s000180050500)

Feinberg MW, Cao Z, Wara AK, Lebedeva MA, Senbanerjee $S$ \& Jain MK 2005 Kruppel-like factor 4 is a mediator of proinflammatory signaling in macrophages. Journal of Biological Chemistry 280 38247-38258. (doi:10.1074/jbc.M509378200)

Fujiu K, Manabe I \& Nagai R 2011 Renal collecting duct epithelial cells regulate inflammation in tubulointerstitial damage in mice. Journal of Clinical Investigation 121 3425-3441. (doi:10.1172/JCl57582)

Ghaleb AM, Nandan MO, Chanchevalap S, Dalton WB, Hisamuddin IM \& Yang VW 2005 Kruppel-like factors 4 and 5: the yin and yang regulators of cellular proliferation. Cell Research 15 92-96. (doi:10.1038/sj.cr. 7290271)

Goldenberg RL, Hauth JC \& Andrews WW 2000 Intrauterine infection and preterm delivery. New England Journal of Medicine 342 1500-1507. (doi:10.1056/NEJM200005183422007)

Goldenberg RL, Culhane JF, lams JD \& Romero R 2008 Epidemiology and causes of preterm birth. Lancet 371 75-84. (doi:10.1016/S01406736(08)60074-4)

Gomez LM, Ma Y, Ho C, McGrath CM, Nelson DB \& Parry S 2008 Placental infection with human papillomavirus is associated with spontaneous preterm delivery. Human Reproduction 23 709-715. (doi:10.1093/ humrep/dem404)

Hayden MS \& Ghosh S 2004 Signaling to NF-кB. Genes and Development 18 2195-2224. (doi:10.1101/gad.1228704)

Herbst-Kralovetz MM, Quayle AJ, Ficarra M, Greene S, Rose WA II, Chesson R, Spagnuolo RA \& Pyles RB 2008 Quantification and comparison of Toll-like receptor expression and responsiveness in primary and immortalized human female lower genital tract epithelia. American Journal of Reproductive Immunology 59 212-224. (doi:10.1111/j.1600-0897.2007.00566.x)

Huang HL, Yang WY, Pu HF, Tsai TH, Lin CH, Chen NJ \& Tarng DC 2013 Kruppel-like factor 5 associates with melamine-cyanurate crystalinduced nephritis in rats. Nephrology, Dialysis, Transplantation 28 2477-2483. (doi:10.1093/ndt/gft308)

Kaczynski J, Cook T \& Urrutia R 2003 Sp1- and Kruppel-like transcription factors. Genome Biology 4 206. (doi:10.1186/gb-2003-4-2-206)

Keelan JA, Blumenstein M, Helliwell RJ, Sato TA, Marvin KW \& Mitchell MD 2003 Cytokines, prostaglandins and parturition - a review. Placenta 24 (Suppl A) S33-S46. (doi:10.1053/plac.2002.0948)

Kumekawa M, Fukuda G, Shimizu S, Konno K \& Odawara M 2008 Inhibition of monocyte chemoattractant protein-1 by Kruppel-like factor 5 small interfering RNA in the tumor necrosis factor- $\alpha$-activated human umbilical vein endothelial cells. Biological \& Pharmaceutical Bulletin 31 1609-1613. (doi:10.1248/bpb.31.1609)
Lappas M \& Rice GE 2004 Phospholipase A2 isozymes in pregnancy and parturition. Prostaglandins, Leukotrienes, and Essential Fatty Acids 70 87-100. (doi:10.1016/j.plefa.2003.04.001)

Lappas M \& Rice GE 2007 The role and regulation of the nuclear factor $\kappa \mathrm{B}$ signalling pathway in human labour. Placenta 28 543-556. (doi:10.1016/j.placenta.2006.05.011)

Lappas M, Permezel M, Georgiou HM \& Rice GE 2002 Nuclear factor $\kappa B$ regulation of proinflammatory cytokines in human gestational tissues in vitro. Biology of Reproduction 67 668-673. (doi:10.1095/biolreprod67.2.668)

Lappas M, Permezel M \& Rice GE 2003 N-acetyl-cysteine inhibits phospholipid metabolism, proinflammatory cytokine release, protease activity, and nuclear factor- $\mathrm{\kappa B}$ deoxyribonucleic acid-binding activity in human fetal membranes in vitro. Journal of Clinical Endocrinology and Metabolism 88 1723-1729. (doi:10.1210/jc.2002-021677)

Lappas M, Permezel M, Georgiou HM \& Rice GE 2004 Regulation of phospholipase isozymes by nuclear factor- $\mathrm{\kappa} B$ in human gestational tissues in vitro. Journal of Clinical Endocrinology and Metabolism 89 2365-2372. (doi:10.1210/jc.2003-031385)

Lappas M, Yee K, Permezel M \& Rice GE 2006 Lipopolysaccharide and TNF- $\alpha$ activate the nuclear factor $\kappa B$ pathway in the human placental JEG-3 cells. Placenta 27 568-575. (doi:10.1016/j.placenta.2005.06.003)

Lappas M, Mitton A, Lim R, Barker G, Riley C \& Permezel M 2011 SIRT1 is a novel regulator of key pathways of human labor. Biology of Reproduction 84 167-178. (doi:10.1095/biolreprod.110.086983)

Lim R, Barker G \& Lappas M 2013a A novel role for FOXO3 in human labor: increased expression in laboring myometrium, and regulation of proinflammatory and prolabor mediators in pregnant human myometrial cells. Biology of Reproduction 88 156. (doi:10.1095/biolreprod.113.108126)

Lim R, Barker G \& Lappas M 2013b SIRT6 is decreased with preterm labor and regulates key terminal effector pathways of human labor in fetal membranes. Biology of Reproduction 88 17. (doi:10.1095/biolreprod. 112.105163)

Lim R, Barker G \& Lappas M 2014 The TLR2 ligand FSL-1 and the TLR5 ligand flagellin mediate pro-inflammatory and pro-labour response via MyD88/TRAF6/NF-KB-dependent signalling. American Journal of Reproductive Immunology 71 401-417. (doi:10.1111/aji.12229)

Liu J, Yang T, Liu Y, Zhang H, Wang K, Liu M, Chen G \& Xiao X 2012 Kruppel-like factor 4 inhibits the expression of interleukin-1 $\beta$ in lipopolysaccharide-induced RAW264.7 macrophages. FEBS Letters $\mathbf{5 8 6}$ 834-840. (doi:10.1016/j.febslet.2012.02.003)

Lu Y, Zhang L, Liao X, Sangwung P, Prosdocimo DA, Zhou G, Votruba AR, Brian L, Han YJ, Gao H et al. 2013 Kruppel-like factor 15 is critical for vascular inflammation. Journal of Clinical Investigation 123 4232-4241. (doi:10.1172/JCl68552)

McConnell BB \& Yang VW 2010 Mammalian Kruppel-like factors in health and diseases. Physiological Reviews 90 1337-1381. (doi:10.1152/ physrev.00058.2009)

McConnell BB, Klapproth JM, Sasaki M, Nandan MO \& Yang VW 2008 Kruppel-like factor 5 mediates transmissible murine colonic hyperplasia caused by Citrobacter rodentium infection. Gastroenterology 134 1007-1016. (doi:10.1053/j.gastro.2008.01.013)

Menon R \& Fortunato SJ 2004 Fetal membrane inflammatory cytokines: a switching mechanism between the preterm premature rupture of the membranes and preterm labor pathways. Journal of Perinatal Medicine 32 391-399. (doi:10.1515/JPM.2004.134)

Noto JM, Khizanishvili T, Chaturvedi R, Piazuelo MB, Romero-Gallo J, Delgado AG, Khurana SS, Sierra JC, Krishna US, Suarez G et al. 2013 Helicobacter pylori promotes the expression of Kruppel-like factor 5, a mediator of carcinogenesis, in vitro and in vivo. PLOS ONE 8 e54344. (doi:10.1371/journal.pone.0054344)

Olson DM 2003 The role of prostaglandins in the initiation of parturition. Best Practice \& Research. Clinical Obstetrics \& Gynaecology 17 717-730. (doi:10.1016/S1521-6934(03)00069-5)

Osman I, Young A, Ledingham MA, Thomson AJ, Jordan F, Greer IA \& Norman JE 2003 Leukocyte density and pro-inflammatory cytokine expression in human fetal membranes, decidua, cervix and myometrium before and during labour at term. Molecular Human Reproduction 9 41-45. (doi:10.1093/molehr/gag001)

Parisi S, Cozzuto L, Tarantino C, Passaro F, Ciriello S, Aloia L, Antonini D, De Simone V, Pastore L \& Russo T 2010 Direct targets of Klf5 
transcription factor contribute to the maintenance of mouse embryonic stem cell undifferentiated state. BMC Biology 8 128. (doi:10.1186/17417007-8-128)

Renthal NE, Chen CC, Williams KC, Gerard RD, Prange-Kiel J \& Mendelson CR 2010 miR-200 family and targets, ZEB1 and ZEB2, modulate uterine quiescence and contractility during pregnancy and labor. PNAS 107 20828-20833. (doi:10.1073/pnas.1008301107)

Romero R, Espinoza J, Goncalves LF, Kusanovic JP, Friel LA \& Nien JK 2006 Inflammation in preterm and term labour and delivery. Seminars in Fetal \& Neonatal Medicine 11 317-326. (doi:10.1016/j.siny.2006.05.001)

Schaefer TM, Desouza K, Fahey JV, Beagley KW \& Wira CR 2004 Tolllike receptor (TLR) expression and TLR-mediated cytokine/chemokine production by human uterine epithelial cells. Immunology 112 428-436. (doi:10.1111/j.1365-2567.2004.01898.x)

Shi H, Zhang Z, Wang X, Liu S \& Teng CT 1999 Isolation and characterization of a gene encoding human Kruppel-like factor 5 (IKLF): binding to the CAAT/GT box of the mouse lactoferrin gene promoter. Nucleic Acids Research 27 4807-4815. (doi:10.1093/nar/27.24.4807)

Shinoda Y, Ogata N, Higashikawa A, Manabe I, Shindo T, Yamada T, Kugimiya F, Ikeda T, Kawamura N, Kawasaki Y et al. 2008 Kruppel-like factor 5 causes cartilage degradation through transactivation of matrix metalloproteinase 9. Journal of Biological Chemistry $28324682-24689$. (doi:10.1074/jbc.M709857200)

Sogawa K, Imataka H, Yamasaki Y, Kusume H, Abe H \& Fujii-Kuriyama Y 1993 cDNA cloning and transcriptional properties of a novel GC boxbinding protein, BTEB2. Nucleic Acids Research 21 1527-1532. (doi:10. 1093/nar/21.7.1527)

Sun X, Zhang L, Xie H, Wan H, Magella B, Whitsett JA \& Dey SK 2012 Kruppel-like factor 5 (KLF5) is critical for conferring uterine receptivity to implantation. PNAS 109 1145-1150. (doi:10.1073/pnas.1118411109)

Sur I, Unden AB \& Toftgard R 2002 Human Kruppel-like factor 5/KLF5: synergy with NF- $\kappa \mathrm{B} /$ Rel factors and expression in human skin and hair follicles. European Journal of Cell Biology 81 323-334. (doi:10.1078/ 0171-9335-00257)

Tsekoura EA, Konstantinidou A, Papadopoulou S, Athanasiou S, Spanakis N, Kafetzis D, Antsaklis A \& Tsakris A 2010 Adenovirus genome in the placenta: association with histological chorioamnionitis and preterm birth. Journal of Medical Virology 82 1379-1383. (doi:10. 1002/jmv.21820)
Turner J \& Crossley M 1999 Mammalian Kruppel-like transcription factors: more than just a pretty finger. Trends in Biochemical Sciences 24 236-241. (doi:10.1016/S0968-0004(99)01406-1)

Wan H, Luo F, Wert SE, Zhang L, Xu Y, Ikegami M, Maeda Y, Bell SM \& Whitsett JA 2008 Kruppel-like factor 5 is required for perinatal lung morphogenesis and function. Development 135 2563-2572. (doi:10. 1242/dev.021964)

Xia H, Wang C, Chen W, Zhang H, Chaudhury L, Zhou Z, Liu R \& Chen C 2013 Kruppel-like factor 5 transcription factor promotes microsomal prostaglandin $E_{2}$ synthase 1 gene transcription in breast cancer. Journal of Biological Chemistry 288 26731-26740. (doi:10.1074/jbc. M113.483958)

Xu P, Alfaidy $\mathbf{N}$ \& Challis JR 2002 Expression of matrix metalloproteinase (MMP)-2 and MMP-9 in human placenta and fetal membranes in relation to preterm and term labor. Journal of Clinical Endocrinology and Metabolism 87 1353-1361. (doi:10.1210/jcem.87. 3.8320)

Young A, Thomson AJ, Ledingham M, Jordan F, Greer IA \& Norman JE 2002 Immunolocalization of proinflammatory cytokines in myometrium, cervix, and fetal membranes during human parturition at term. Biology of Reproduction 66 445-449. (doi:10.1095/biolreprod66.2.445)

Zahlten J, Steinicke R, Opitz B, Eitel J, N'guessan PD, Vinzing $M$, Witzenrath M, Schmeck B, Hammerschmidt S, Suttorp N et al. 2010 TLR2- and nucleotide-binding oligomerization domain 2-dependent Kruppel-like factor 2 expression downregulates NF- $\mathrm{BB}$-related gene expression. Journal of Immunology 185 597-604. (doi:10.4049/jimmunol.0901798)

Zhang Y, Lei CQ, Hu YH, Xia T, Li M, Zhong B \& Shu HB 2014 Kruppel-like factor 6 is a co-activator of NF- $\mathrm{B}$ that mediates p65-dependent transcription of selected downstream genes. Journal of Biological Chemistry 289 12876-12885. (doi:10.1074/jbc.M113.535831)

Received 12 November 2014

First decision 19 December 2014

Revised manuscript received 6 February 2015

Accepted 16 February 2015 